\title{
Success factors for demonstration projects of small-scale stationary fuel cells in residential buildings
}

\author{
Guenter Simader ${ }^{1, *}$, Patrick Vidovic ${ }^{1}$ \\ ${ }^{1}$ Austrian Energy Agency, Mariahilfer Straße 136, 1150 Vienna, Austria
}

\begin{abstract}
Worldwide small-scale micro-CHPs account for the largest share in the fuel cell market by units of installation (not by installed power output). Notably, the Japanese Ene-Farm program is responsible for over 400.000 micro-CHP fuel cell installations (until the end of June 2021). This is the largest worldwide deployment program and it reflects the long- and outstanding commitment of both the Japanese government and the Japanese industry to form a 'Hydrogen Society'. In Europe, the situation is entirely different. European projects like PACE financed by the European joint undertaking for hydrogen and fuel cells give a positive impulse for fuel cell based micro-CHP, however it has to be judged as insufficient for a market transformation measure. Presently, only Germany, notably by the KFW433 program, is providing frame conditions for a rollout of fuel cell based micro-CHP systems. This article analyses the success factors for the implementation of Ene-Farm systems in Japan. It compares the different frame conditions of Japan and European countries like Austria and discusses the question whether an Ene-Farm project based on the Japanese success factors could be replicated in Austria. On a bird's eye, a European perspective will be derived from the analysis.
\end{abstract}

\section{Introduction}

Typical use cases for stationary fuel cells are large stationary prime power plants, combined heat and power (CHP), uninterruptible power supplies (UPS), larger 'permanent' APUs and small scale stationary micro-CHP supplies. Small-scale micro-CHPs account for the largest share in the fuel cell market by units of installation (not by installed power output). (1)

Notably, the Japanese Ene-Farm program is responsible for over 400.000 micro-CHP fuel cell installations (until the end of June 2021). (2) This is the largest worldwide deployment program for residential fuel cells and it reflects the long- and outstanding commitment of both the Japanese government and the Japanese industry to form a 'Hydrogen society'.

This high-volume market also made it possible to drive the technology along the learning curve and generate substantial economies of mass production. Successful product developments could be achieved in highly competitive markets.

The prime products of Ene-Farm program are presently a PEM-based technology from Panasonic and a SOFCbased technology from Aisin and Kyocera. The products have a typical electrical power output of $700 \mathrm{~W}$ (and even lower). They operate on natural gas or LPG. Japan's gas companies, like Tokyo Gas or Osaka Gas, mainly supply the units.
The climate conditions in Central and Northern European countries (like Austria) make heating systems necessary to cover the heating and domestic hot water demand. However, with exception of Germany, fuel cell based micro-CHP systems (or conventional ones) are not installed in large quantities in residential and/or nonresidential buildings like in Japan.

This article analyses the success factors for the implementation of Ene-Farm systems in Japan. It compares the different frame conditions of Japan and European countries like Austria and discusses the question whether an Ene-Farm project based on the Japanese success factors could be replicated in Austria. On a bird's eye, a European perspective will be derived from the analysis.

\section{Success factors of the Japanese Ene- Farm project}

For the Japanese Ene-Farm project, the following success factors could be identified:

- Clear strategic positioning with clear strategic goals (embedded in an overall country's R\&D strategy) by establishing a level playing field for micro-C

- Ene-Farm systems are recognized as greenhouse-gas abatement technology (contributing to national energy and climate policy goals)

\footnotetext{
* Corresponding author: guenter.simader@energyagency.at
} 
- Excellent product quality and availability, simple distribution channels and system installation (by one-stop-shops)

- Product characteristics (power output of microCHPs) meet the market requirements of Japanese households/buildings (domestic hot water demand and electricity demand)

- High-volume markets enable product standardisation, product iterations/improvements and significant cost reductions

- Micro-CHP systems increase the resilience of the energy system (in case of natural disasters like earthquakes, hurricanes, ...)

In the following, the success factors are analyzed and the applicability and replicability for the Austrian (European) market are examined.

\subsection{Clear strategy and clear goals for micro-CHP systems}

As already pointed out, hydrogen and fuel cells are central elements of the Japanese energy and climate policy to form a 'Hydrogen Society'. Goals for stationary fuel cells ('Ene-Farms') are the implementation of 5.3 million systems until $2030 \quad(10 \%$ of Japanese households). The target price for PEM based Ene-Farm systems is $¥ 800.000$ (ca. $€ 6.500$ ) and $¥ 1.000 .000$ (ca. $€$ 8.000 ) for SOFC based systems. The payback period of 5 years should be achieved at this time. (3)

In Europe, the frame conditions are (entirely) different to the Japanese ones. Although there is a hydrogen strategy in place, the primary goal is to achieve the reduction of $\mathrm{CO}_{2 \text { eq }}$ by $55 \%$ until 2030 and to achieve climate neutrality by 2050 (with hydrogen as one element in the puzzle). $(4,5)$ Austria, even more ambitious, has the goal of climate neutrality by 2040 . The discussion of the role of 'green' hydrogen is still ongoing.

In order to reach the goal of climate neutrality, fossil fuels should continuously phase-out from all sectors. In Austria, there is a Renewable Heat Act in preparation to ban fossil fuels by 2040. Prior to this, a commandment for systems based on renewable energy sources will be implemented accompanied by extensive subsidy schemes in order to start to phase-out fossil fuels by 2025 . These systems are seen to result in $\mathrm{CO}_{2}$ lock-in effects of fossil fuels and to prevent the transition to climate neutrality.

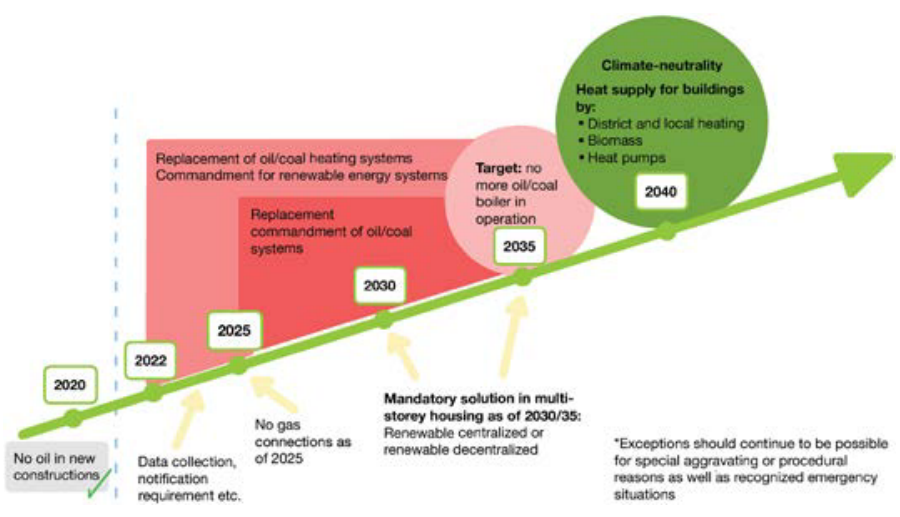

Fig. 1. Key points of the planned Austrian Heat Act implementing renewable based heating systems to reach climate neutrality by 2040

'Green'-hydrogen or 'renewable gases or E-fuels' will fit into the strategy of climate neutrality. However, the quantities of 'green' gases/fuels are presently classified as very limited and expensive. Significant quantities of 'green' hydrogen are expected by 2030 .

Moreover, this 'green' hydrogen (also applicable for renewable gases or E-fuels) are foreseen to be used in sectors with no other technological options. Examples for sectors with limited technological options to become climate neutral are seen in the heavy industry (e.g., steel industry, cement industry,) or in the transportation sector (long distance freight transportation).

The use cases in the building sector offer many technological options for fossil-free heating systems (like heat pumps, biogenic systems, etc.). Many innovations based on renewable energy sources are presently tested and implemented in Austria. (6)

\subsection{Ene-Farm systems are recognized as greenhouse-gas abatement technology (contributing to national energy and climate policy goals)}

Fossil generation capacities account for more than $80 \%$ (mainly coal and gas) in the Japanese power generation. In Austria, this share is only about $17 \%$ (regardless of imports). Accordingly, the $\mathrm{CO}_{2 \text { eq }}$ intensities of grid electricity in the two countries differ significantly. While Japan had a high value of $464 \mathrm{~g} / \mathrm{kWh} \mathrm{CO} \mathrm{Ceq}_{2 \mathrm{i}} 2017$ (7), Austria was most recently at $227 \mathrm{~g} / \mathrm{kWh} \mathrm{CO} \mathrm{Ceq}_{2}$.

When operating an Ene-Farm system based on fossil fuels in Japan, the achievable savings in greenhouse gases are much higher than in Austria. In Austria, only marginal savings can be achieved. Using renewable gases or 'green' hydrogen in micro-CHP systems could increase these savings tremendously (see figure 3). However, as already pointed out, the building sector is not seen as priority use case for the deployment of 'green' hydrogen or renewable gases. 

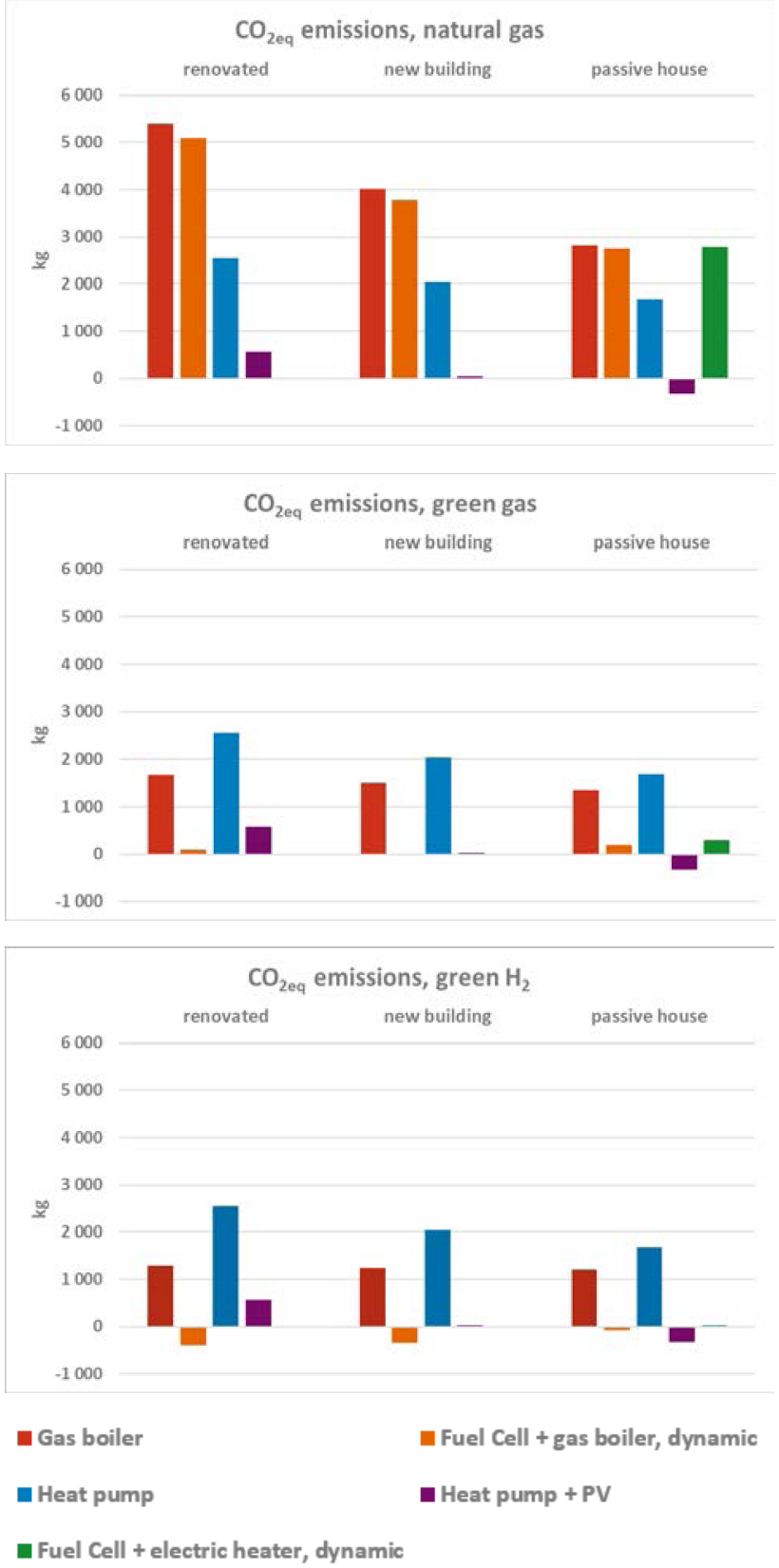

Fig. 2. Comparison of $\mathrm{CO}_{2 \mathrm{eq}}$ emissions of fuel cell based micro-CHP heating systems with competing technologies in single family houses in Austria (for three building standards: renovated, new building and passive house) fuelled by natural gas, 'green' gas and 'green' hydrogen with competing technologies (like gas condensing boiler, heat pump w/o PV) (8) Reading: The second column shows the results of the micro-CHP system, respectively. Only when fuelled with 'green' gas or 'green' hydrogen significant $\mathrm{CO}_{2 \mathrm{eq}}$-savings can be achieved.

\subsection{Excellent product quality and availability, simple distribution channels and system installation (by one-stop-shops)}

The distribution channels of Ene-Farm products are very simple for end customers. There are currently three manufacturers of Ene-Farms (Aisin, Kyocera and
Panasonic), and sales are handled entirely by local gas utilities (e.g., Osaka Gas, Tokyo Gas, etc.).(3)

The utilities also take care of the installation and maintenance of the equipment as well as of suitable energy supply contracts, thus forming a one-stop shop for customers. Furthermore, the installation of Ene-Farm devices are not very costly, as the investment costs are low (compared to Europe) and they are mainly installed outside of the buildings. Thanks to the optimized systems, durability of the cell stack, that is the main device of the system, the service life of the power generation unit has been extended from 10 to 12 years. (10)

The typical system configuration of an Ene-Farm system is shown in the figure below.

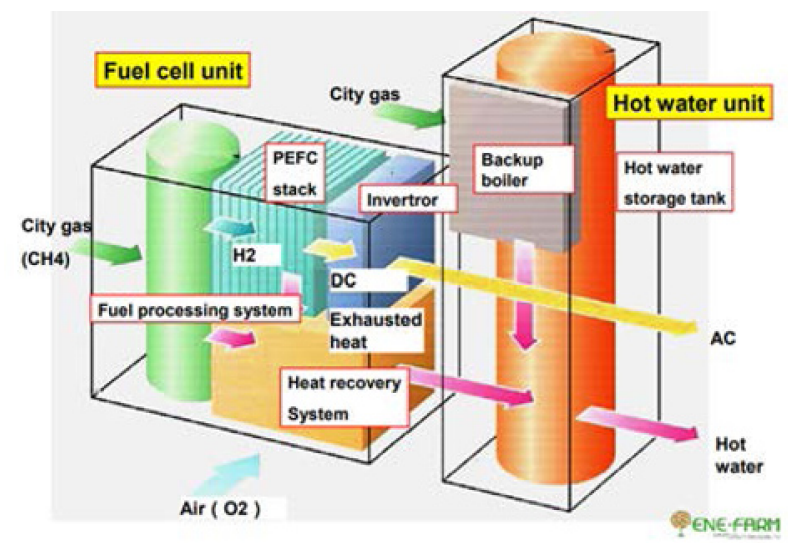

Fig. 3. Typical system configuration of an Ene-Farm system (3)

In Austria, stationary micro-CHP systems based on fuel cells are mainly sold directly by the manufacturers or their installer companies (no one-stop store). Usually, the manufacturers or their installers have a product portfolio of different heating systems (from heat pumps, biogenicbased systems to gas condensing boilers, and micro-CHP systems). The owner must conclude gas supply contracts and network access contracts.

In contrast to Japan, heating systems in Austria are installed indoors. The regulatory requirements for indoor installations are notably higher (due to safety regulations) and the installations are more complex than outdoors. In addition, there are bureaucratic barriers in Austria that make the installation of a micro-CHP system in buildings more difficult (e.g., issuance of an energy performance certificate (EPC) in case of a new building or a deep renovation).

Thus, there is a very competitive environment for microCHP systems offering very weak unique selling propositions to the end user.

\subsection{Product characteristics of Ene-Farm systems are optimized to the required Japanese demand profiles in residential buildings}


Ene-Farm systems in Japan are operated following the electrical demand of the building as long as the required hot water demand is produced. First and foremost, the hot water demand is provided by the Ene-Farm system, during this time the system also provides power to the building. In case of a higher hot water demand, a backup boiler provides this demand. The power grid covers a higher electricity demand.

The operating modes of Ene-Farm systems are shown exemplarily for two single-family houses (in the following figure). The use of Ene-Farm systems in condominiums is also possible (if space conditions allow the installation of the system).

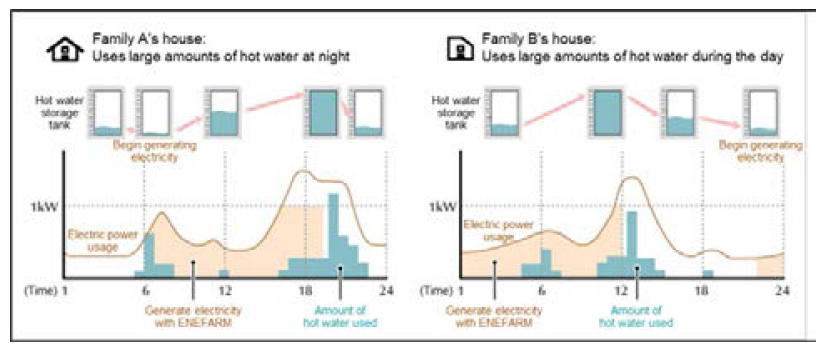

Fig. 4. Typical operation modes of Ene-Farm systems (8)

The following table lists the product characteristics of the three relevant manufacturing companies. The power ratings of Ene-Farm systems were optimized in order to meet the daily hot water demand (about 150 liters and lower) and to achieve a long daily operation period. Over the years, the electrical power output decreased slightly from $1 \mathrm{~kW}$ to $700 \mathrm{~W}$ ). Kyocera's system with $400 \mathrm{~W}$ has been dimensioned smaller enabling even longer daily operating periods.

Table 1. Product characteristics (2)

\begin{tabular}{|l|l|l|l|l|}
\hline Company & Type & $\begin{array}{l}\text { Electrical } \\
\text { Power } \\
\mathbf{k W}\end{array}$ & $\begin{array}{l}\text { Electrical } \\
\text { Efficiency } \\
\mathbf{\%}\end{array}$ & $\begin{array}{l}\text { Total } \\
\mathbf{\%}\end{array}$ \\
\hline Panasonic & PEFC & 0,7 & 40 & 97 \\
\hline Aisin & SOFC & 0,7 & 55 & 87 \\
\hline Kyocera & SOFC & 0,4 & 47 & 80 \\
\hline
\end{tabular}

Due to the climate conditions in Austria the energy demand for heating in single family houses $(50-225$ $\mathrm{kWh} / \mathrm{m}^{2} \mathrm{a}$ ) is significantly higher than in Japan (about 12 $\mathrm{GJ} /$ household year). ${ }^{\text {a }}$ The domestic hot water demand is

a The way of looking to the energy consumption in buildings, respectively households is different in Austria compared to Japan. In Austria, the typical usable floor area in single-family houses is between 115 and $150 \mathrm{~m}^{2}$ (to make the numbers between Austria and Japan comparable). about $10 \mathrm{kWh} / \mathrm{m}^{2} \mathrm{a}$, only a small part compared to the heating demand.

In Austria, central heating systems (including boiler, distribution and dissipation system - radiators) are the standard to cover the heat and domestic hot water demand. Presently, typical central heating systems are fossil-fuelled (oil, gas), renewable energy-based (biomass, heat pumps) or connected to the district heating system.

The central heating system continuously charges the hot water storage tank. In case of using condensing gas combi boilers, a storage system is not even required. In fewer cases, electric water heaters or instantaneous water heaters are used. Investment costs for these systems are quite low (about $€ 100$ and above). Another - more efficient and more expensive - option are domestic hot water heat pumps (about $€ 1.000$ to $€ 2.000$ ).

Comparing the total costs of ownership of different heating options in single family houses (including microCHP systems) show very limited economic performance (see next chapter). The economic advantages that can be realized for users of Ene-Farm systems in Japan cannot be transferred to the Austrian situation.

\subsection{Market volume generates improved product iterations and competitive product prices}

As already pointed out, over 400,000 Ene-Farm systems were successfully installed in Japan by 2020 (mainly outside of buildings). Although Japan was not able to reach its own target of 1.4 million systems by 2020, a mass market was established for fuel cell based microCHP systems.

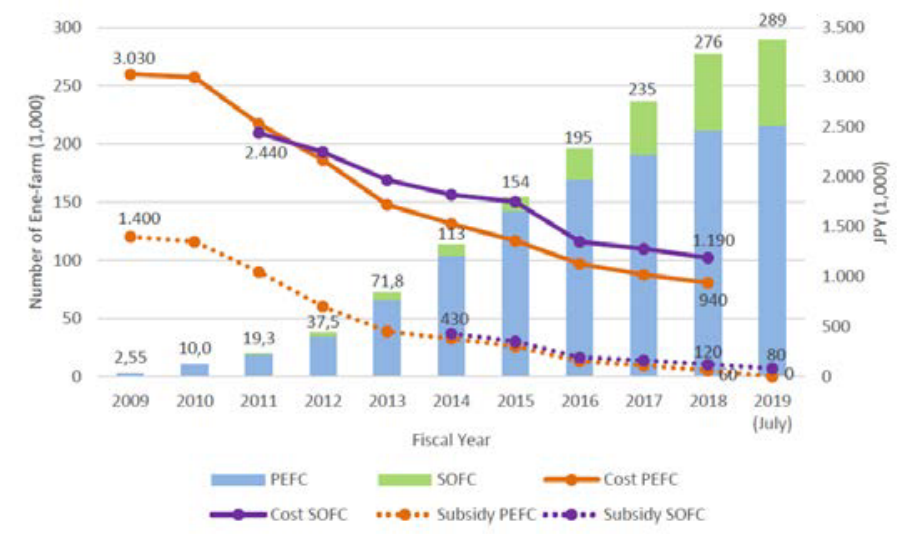

Fig. 5. Commercialisation of Ene-farm stationary fuel cell systems in Japan until 2019, evolution of costs and subsidies [3]

By 2030, a target of 5.3 million installations (about $10 \%$ of Japanese households) were announced by METI as part of the strategic roadmap for hydrogen and fuel cells. The clear framework conditions enable the manufacturing companies to establish mass production of these systems, 
to significantly reduce the price of the systems (between $€ 7,000$ and $€ 9,300$ by 2021 ), and to develop business models for distribution. (3)

By achieving a mass market, it was possible to continuously improve the product characteristics in terms of compactness, integration into the building automation, higher supply security, higher efficiency and improved sale possibilities of produced electricity. In terms of costeffectiveness, payback periods below 10 years (goal 5 years by 2030) were achieved.

In Europe, the situation is entirely different. European projects like PACE financed by the European Joint Undertaking for hydrogen and fuel cells give a positive impulse for fuel cell based micro-CHP, however it has to be judged as insufficient for a market transformation measure. Presently, only Germany, notably by the KFW433 program, provided frame conditions for a rollout of over 15.000 fuel cell based micro-CHP systems in the last few years.

The typical investment costs of fuel cell based microCHP systems for single-family houses are much higher in Austria (but also in Germany) than in Japan. Depending on the system configuration, the manufacturer announces system prices between $€ 25.000$ and $€ 35.000$ (incl. VAT). The following figure shows the fuel cell based micro-CHP system installed most often in Austria (from Viessmann Company).

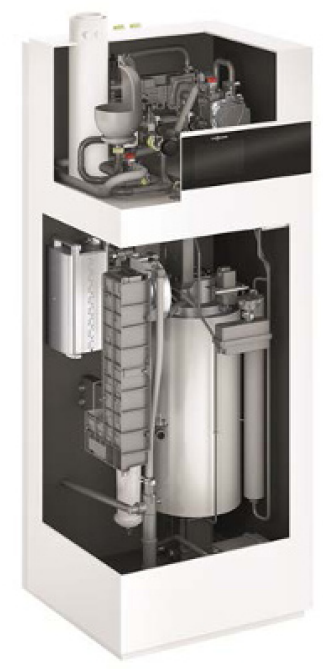

(a) courtesy of Viessmann Company

Fig. 6. Vitovalor PT 2 based on PEM-LT technology $\mathrm{P}_{\mathrm{el}}$ : $\quad 750 \quad \mathrm{~W}, \quad \mathrm{P}_{\text {th }}$ $1,1 \quad \mathrm{~kW}_{\text {th }}$ $\mathrm{P}_{\text {th }}$ from gas boiler: individual scalable from $11,4 \mathrm{~kW}$, 24,5 kW to $30,8 \quad \mathrm{~kW}$ Hot water storage tank: 2201

The prices for electricity and gas is unfavourable for realising benefits of produced electricity (ratio: electricity/gas is in Austria 2:1; in Germany much better with 4:1). A comparison of the total cost of ownership (TCO) of different heating systems shows that a fuel cellbased micro-CHP system is challenging (see Figure 8).
For this comparison, three scenarios were developed, comparing micro-CHP fuel cell systems with gas condensing boilers and heat pumps (w/o photovoltaic):

Scenario 1: Austrian prices: for the investment of the heating system, for gas and electricity (purchase and feed-in) and for O\&M (operation and maintenance)

Scenario 2: Scenario 1 using Japanese Ene-Farm investment costs for the micro-CHP system, all other parameters follow Scenario 1

Scenario 3: Scenario 1 including a subsidy scheme (similar to the KfW 433 scheme $^{b}$ ) and German prices for gas and electricity

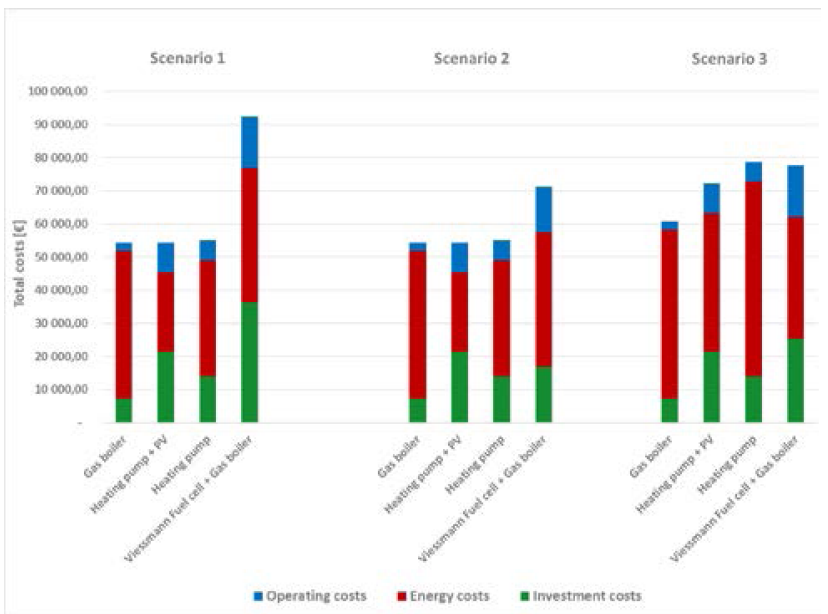

Fig. 7. Comparison of the total cost of ownership (TCO) between micro-CHP system (incl. gas boiler) and gas condensing boiler, electrically heat pump (w/o photovoltaic) in single-family houses. Reading: Only with a subsidy scheme like Germany's KfW 433 and ratios of gas/electricity prices of $4: 1$, the micro-CHP system can achieve a similar economic performance like a heat pump (scenario 3). Presently, competing systems have a very similar TCO level in Austria (scenario 1). Scenario 2 shows that even with price levels for the fuel cell like in Japan, a fuel cell micro-CHP achieves no economic advantage (due to other unfavourable economic frame conditions).

In Austria, subsidy schemes similar to the German KfW 433 program must be implemented in order to achieve similar TCO for fuel cell based micro-CHP systems.

Economic analysis of fuel cell systems with a higher power output deployed in larger buildings (more family houses and/or non-residential buildings) with long annual operation hours of the fuel cell improve the economic performance of micro-CHP fuel cell systems.

\footnotetext{
${ }^{b}$ The subsidy scheme of KfW 433 provides a fixed amount of $€ 6.800$ and additionally a power-dependent amount of $€ 550$ per $100 \mathrm{~W}$ of electrical power or part thereof.
} 


\subsection{Micro-CHP systems increase the resilience of the energy system (in case of natural disasters like earthquakes, hurricanes ...)}

The resilience of power systems due to natural disasters (such as earthquakes, hurricanes, etc.) has a completely different meaning in Japan compared to Austria (or Europe). In Japan, long outages of the power grid with far-reaching consequences can occur (in case the transmission system is affected). Accordingly, decentralized systems for energy supply that increase the resilience of the energy system are regarded as very positively by the society.

Ene-Farms can be operated in parallel to the grid as emergency power systems. If a power failure occurs, the Ene-Farm system will take over the energy supply. This allows the use of, for example, smaller electrical appliances and/or the lighting system (even during a power outage). In addition, domestic hot water is produced. This feature offers an excellent additional selling point for Ene-Farm systems in Japan. Ene-Farm companies receive very often awards like the "Japan Resilience Award".

In Austria, power outages due to unplanned regional extraordinary events such as floods, snowstorms are less frequent (between 10 to 20 minutes per year in the last 10 years). The importance of using a stationary fuel cell as emergency power system is less relevant and is not a common purchase argument.

\section{Conclusions}

Hydrogen and fuel cells are central elements of the Japanese energy and climate policy to form a 'Hydrogen Society' in all sectors. The implementation of the 'EneFarms' project resulted in over 400.000 installed units by the End of June 2021. By 2030, a target of 5.3 million installations (about $10 \%$ of Japanese households) were announced by METI.

The clear frame-conditions made it possible to achieve a mass market for Ene-Farm systems in the residential sector. It was possible to continuously improve the product characteristics in terms of compactness, integration into the building automation, higher supply security (resilience), higher efficiency and improved sale possibilities of produced electricity. In terms of costeffectiveness, lower prices were achieved and payback periods of 7 to 8 years are reported (with the target of 5 years in 2030).

The Ene-Farm project may be characterised as a success story yet unequalled in the world!

In Europe, the frame conditions are (entirely) different to the Japanese ones. Although, there is a hydrogen strategy in place, the primary goal is to achieve the reduction of $\mathrm{CO}_{2 \text { eq }}$ by $55 \%$ until 2030 and to achieve climate neutrality by 2050 (with hydrogen as one element in the puzzle). $(4,5)$ Austria, even more ambitious, has the goal of climate neutrality by 2040 .

Presently, the discussion of climate neutrality unfavourable influences the usage of micro-CHP systems based on fossil fuels. These systems are seen to result in $\mathrm{CO}_{2}$ lock-in effects of fossil fuels and to prevent the transition to climate neutrality. The role of 'green' hydrogen in our future energy system is still ongoing.

The question whether the Japanese Ene-Farm project can/should be replicated in Austria's residential building sector is very difficult to be answered positively. Identified success factors for the Japanese Ene-Farm project cannot be transferred to Austria. Besides the mentioned unfavourable political frame-conditions, many barriers were identified concerning technological requirements for heating systems, economic competitiveness and acceptance as climate abatement technology.

Nevertheless, the future of stationary fuel cells is seen very positive (but not based on fossil fuels). The strategy of climate neutrality will increase the amounts of renewable energy sources in our energy system in the next few years significantly. In parallel to the generated electrical energy, energy vectors like hydrogen and/or other synthetic fuels are regarded to be necessary for our future energy system.

Looking to a fossil-free energy future, fuel cells in combination with hydrogen from renewable energy sources (like photovoltaic, wind, small hydropower) will be the core element of decentralised, hydrogen-based eco-systems providing electricity (and waste heat) to households, mobility applications as well as the trade and commerce sector.

\section{Acknowledgement}

This project receives support by the Austrian IEA research cooperation on behalf of the Federal Ministry for Climate Action, Environment, Energy, Mobility, Innovation and Technology.

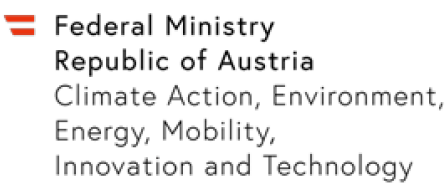

IEA Research Cooperation
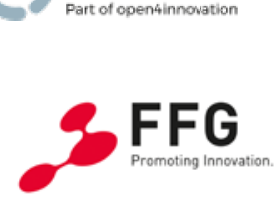


\section{References}

1. E4 Tech, The Fuel Cell Industry Review 2020, March 2021, ()

2. The Japan Gas Association, news release, Cumulative sales of household fuel cell "ENEFARM" exceeded 400,000 units, 5 ${ }^{\text {th }}$ August 2021 (https://www.gas.or.jp/newsrelease/)

3. J. Arias, Hydrogen and Fuel Cells in Japan. Report from the EU-Japan Centre for Industrial Cooperation 2019

4. European Commission, European Green Deal: Commission proposes transformation of EU economy and society to meet climate ambitions, Brussels, 14th July 2021 (https://ec.europa.eu/commission/presscorner/detail/e n/IP 21_3541)

5. European Commission, The role of hydrogen in meeting our 2030 climate and energy targets, Brussels, July 2021 (https://ec.europa.eu/commission/presscorner/detail/e n/fs_21_3676

6. Showcase projects using renewable energy sources in the city of Vienna, 2021 (https://www.wien.gv.at/stadtentwicklung/energie/wi ssen/erneuerbar/index.html

7. Ministry of Economy, Trade and Industry (METI), Agency for Natural Resources and Energy. Japan's Energy 2018. 10 questions for understanding the current energy situation. 2019. (https://www.enecho.meti.go.jp/en/category/brochure s/pdf/japan energy 2018.pdf)

8. G. Simader, et.al., Conception of an Austrian fuel cell demonstration project - Ene-Farm Austria, Report, Vienna, 2022 (in preparation)

9. Itochu Enex Co. Ltd, ENEFARM (Residential Fuel Cells), July 2021 (https://www.itcenex.com/en/business/detail/enefarm /index.html)

10. Osaka Gas Co., News release, February 2020 (https://www.osakagas.co.jp/en/whatsnew/ icsFiles /afieldfile/2020/03/03/20200225.pdf)

11. K. Kordesch, G. Simader, Fuel Cells and their Applications, Wiley-VCH, 1996 